\title{
PENGARUH PERPUTARAN PIUTANG USAHA DAN PERPUTARAN PERSEDIAAN TERHADAP PROFITABILITAS PADA PERUSAHAAN FOOD AND BEVERAGE YANG TERDAFTAR DI BURSA EFEK INDONESIA
}

\author{
Elvi Yanti, Lidya Martha \\ Prodi Manajemen, Sekolah Tinggi Ilmu Ekonomi KBP \\ Email: elvi96.yanti@gmail.com \\ Email Pembimbing: lidyam83@gmail.com
}

\begin{abstract}
This research as a purpose to know what influence of receivable turnover for profitability, Influence of inventory turnover for profitability. Objects are selected by the researchers is a food and beverage company listed on the Indonesia Stock Exchange. The research was conducted to observations in 2011-2015. This type of data is secondary data. The data collected from the official website of the Indonesia Stock Exchange in the form of financial statements. While this sample was determined by purposive sampling method, obtained sample from this research is ten companies food and beverage companies listed on the Indonesian stock exchange. Data analysis technique used is multiple linear regression, F-test, $t$-test and , $R^{2}$-test using Eviews program. Based on the test results $F$ note that the value is significantly smaller than 0.05 in the amount of 0.020929, this shows that the independent variables receivable turnover and inventory turnover simultaneously significant effect on profitability. Based on t test known that Accounts Receivable Turnover does not significantly affect profitability, as indicated by the probability of $>0.05$ is 0.7164 . Unlike the Inventory Turnover significantly affect profitability, as indicated by the probability of $<0.05$ is 0.0061 . Based on the test $R^{2}$ note that the value of 0.151713 , this shows that the profitability of food and beverage companies listed on the Stock Exchange value of 15,17\% can be explained by its two independent variables together that is receivable turnover and inventory turnover. While the rest is determined by variables outside of the study, for example, sales, corporate profits, and accounts payable.
\end{abstract}

Keywords: Accounts Receivable Turnover, Inventory Turnover and Profitability

\section{ABSTRAK}

Penelitian ini bertujuan untuk mengetahui apakah ada pengaruh perputaran piutang usaha terhadap tingkat profitabilitas, Pengaruh perputaran persediaan terhadap tingkat profitabilitas. Obyek yang dipilih oleh peneliti adalah perusahaan food and beverage yang terdaftar pada Bursa Efek Indonesia. Penelitian dilakukan untuk pengamatan pada 2011-2015. Jenis data adalah data sekunder. Data tersebut dikumpulkan dari situs resmi Bursa Efek Indonesia dalam bentuk laporan keuangan. Sedangkan sampel penelitian ini ditentukan dengan metode purposive sampling, sehingga diperoleh sepuluh sampel perusahaan food and beverage yang terdaftar di bursa efek indonesia. Teknik analisis data yang digunakan adalah regresi linier berganda, uji $\mathrm{F}$, uji $\mathrm{t}$, dan uji $\mathrm{R}^{2}$ dengan menggunakan program Eviews. Berdasarkan hasil uji F diketahui bahwa nilai signifikan lebih kecil dari 0,05 yaitu sebesar 0,020929, hal ini menunjukkan bahwa variable bebas perputaran piutang usaha dan perputaran persediaan secara simultan berpengaruh signifikan terhadap profitabilitas. Berdasarkan uji t diketahui bahwa Perputaran Piutang Usaha berpengaruh positif dan tidak signifikan terhadap profitabilitas, yang ditunjukkan dengan probabilitas > 0,05 yaitu 0,7164. Berbeda dengan Perputaran Persediaan berpengaruh positif dan signifikan terhadap Profitabilitas, yang ditunjukkan dengan probabilitas $<0,05$ yaitu 0,0061 . Berdasarkan uji $\mathrm{R}^{2}$ diketahui bahwa nilai $\mathrm{R}^{2}$ sebesar 0.151713 , hal ini menunjukkan bahwa profitabilitas perusahaan food and beverage yang terdaftar di BEI sebesar 15,17\% dapat dijelaskan oleh dua variabel independent-nya secara bersamasama yaitu perputaran piutang usaha dan perputaran persediaan. Sedangkan selebihnya ditentukan oleh variabel diluar penelitian ini, misalnya penjualan, laba perusahaan, dan utang usaha.

Kata kunci: Perputaran Piutang Usaha, Perputaran Persediaan dan Profitabilitas. 


\section{PENDAHULUAN}

Setiap perusahaan harus menerapkan sistem manajemen yang sesuai dengan prosedur agar dapat berkembang dan menjalakan usahanya dengan efektif. Manajemen tersebut digunakan untuk mengatur dan mengontrol kegiatan operasional perusahaan. Keberhasilan manajemen dalam mengelola perusahaan pembiayaan adalah dengan melihat seberapa efektif penggunaan piutang, dan persediaan untuk mendapat profitabilitas.

Salah satu tujuan perusahaan adalah menghasilkan laba. Profitabilitas menurut Harahap (2006) adalah bahwa profitabilitas menggambarkan kemampuan perusahaan mendapatkan laba melalui semua kemampuan dan sumber daya yang ada seperti kegiatan penjualan, kas, modal, jumlah karyawan, jumlah cabang, dan sebagainya. Oleh karena itu perusahan harus mempunyai kemampuan atau profitabilitas yang baik untuk masa depan perusahaan.

Menurut Kasmir (2010) ada beberapa alat ukur yang digunakan untuk menghitung profitabilitas antaranya yaitu profit margin, return on invesment, dan return on equity. Pada penelitian profitabilitas diukur dengan menggunakan return on invesment (ROI).

Pada sebuah perusahaan piutang dan persediaan mempunyai peranan penting, dimana piutang dan persediaan akan dapat mempengaruhi keuntungan yang akan didapatkan oleh sutu perusahaan. Perputaran piutang usaha menurut Bambang (1997) merupakan rasio yang digunakan untuk mengukur berapa lama penagihan piutang menjadi kas selama periode tertentu. Tinggi rendahnya perputaran piutang usaha mempunyai efek yang langsung terhadap besar kecilnya dana yang diinvestasikan pada piutang. Jika tingkat perputaran piutang tinggi berarti pengembalian dana yang tertanam dalam piutang berlangsung cepat sehingga risiko kerugian piutang dapat diminimalkan.

Perputaran persediaan menurut Munawir (2004) adalah perputaran persediaan menunjukkan berapa kali persediaan yang dimiliki perusahaan diganti atau dijual selama periode tertentu. Jika adanya investasi yang terlalu kecil dalam persediaan akan mempunyai efek yang menekan keuntungan, karena kekurangan material perusahaan tidak dapat bekerja dengan luas produksi yang optimal.

Tanpa adanya piutang usaha dan persediaan bagaimana suatu perusahaan menjalankan usahanya dan mendapatkan keuntungan. Semakin tinggi nilai perputaran piutang usaha menunjukkan perusahaan telah menerapkan kebijakan pengumpulan piutang yang baik dan efisien. Begitupun dengan perputaran persediaan, apabila laju perputaran persediaan dalam perusahaan tinggi, maka perusahaan akan mendapatkan peningkatan penjualan, otomatis jika penjualan meningkat maka laba perusahaan juga akan meningkat.

Penelitian yang dilakukan oleh Meria Fitri (2012) menunjukkan bahwa perputaran piutang usaha dan perputaran persediaan mempunyai hubungan yang negatif signifikan terhadap profitabilitas pada perusahaan otomotif dan komponennya yang terdaftar di BEI. Tetapi hasil penelitian berbeda yang dilakukan oleh Putra (2012) menunjukkan bahwa perputaran piutang usaha dan perputaran persediaan berpengaruh signifikan pada perusahaan tekstil yang terdaftar di BEI.

Berdasarkan latar belakang di atas, maka penulis tertarik untuk melakukan penelitian tentang "Pengaruh Perputaran Piutang Usaha dan Perputaran Persediaan terhadap Tingkat Profitabilitas pada Perusahaan Food and Beverage yang Terdaftar di Bursa Efek Indonesia". 
Adapun masalah yang dapat dirumuskan pada penelitian ini adalah sebagai berikut:

1. Bagaimana pengaruh perputaran piutang usaha terhadap tingkat profitabilitas pada perusahaan food and beverage yang terdaftar di BEI tahun 2011-2015 ?

2. Bagaimana pengaruh perputaran persediaan terhadap tingkat profitabilitas pada perusahaan food and beverage yang terdaftar di BEI tahun 2011-2015 ?

Sedangkan tujuan dari penelitian ini adalah sebagai berikut:

1. Untuk menguji pengaruh perputaran piutang usaha terhadap tingkat profitabilitas pada perusahaan food and beverage yang terdaftar di BEI tahun 2011-2015.

2. Untuk menguji pengaruh perputaran persediaaan terhadap tingkat profitabilitas pada perusahaan food and beverage yang terdaftar di BEI tahun 2011-2015.

\section{LANDASAN TEORI DAN HIPOTESIS \\ Pengertian Profitabilitas}

Profitabilitas adalah kemampuan perusahaan dalam menghasilkan laba dan dapat diukur dengan rasio. Menurut Brigham dan Weston (2001) profitabilitas adalah hasil akhir dari serangkaian kebijakan dan keputusan manajemen, dimana kebijakan dan keputusan ini menyangkut pada sumber dan penggunaan dana dalam menjalankan operasional perusahaan yang telah terangkum di dalam laporan neraca dan unsur-unsur dalam neraca yang ditunjukkan oleh rasio-rasio keuangan. Menurut Riyanto (2008) mengatakan bahwa kemampuan perusahaan untuk mendapatkan laba selama periode tertentu. Sedangkan menurut Wiagustini (2010) profitabilitas adalah kemampuan perusahaan memperoleh laba atau efektivitas pengelolaan manajemen perusahaan. Jenis-jenis profitabilitas menurut Kasmir (2010) adalah profit margin, return on invesment (ROI), dan return on equity (ROE). Alat ukur yang dipakai untuk menghitung profitabilitas adalah ROI. Dimana ROI itu sendiri adalah salah satu bentuk dari rasio profitabilitas yang dimaksudkan untuk mengukur kemampuan perusahaan dengan keseluruhan dana yang ditanamkan dalam aktiva yang digunakan untuk operasi perusahaan untuk menghasilkan keuntungan.

\section{Pengertian Perputaran Piutang Usaha}

Menurut Warren (2005) dalam Putriwati (2016) piutang usaha adalah perushaan mempunyai hak klaim terhadap seseorang atau perusahaan lain dengan adanya hak klaim ini perusahaan dapat menuntut pembayaran dalam bentuk uang atau penyebaran asset atau jasa lain kepada pihak dengan siapa ia berpiutang. Piutang merupakan salah satu unsur dari aktiva lancar dalam meraca perusahaan yang timbul akibat adanya penjualan barang dan jasa atau pemberian kredit terhadap debitur yang pembayarannya diberikan dalam tempo tiga puluh hari sampai dengan sembilan puluh hari. Menurut Bambang (2016) perputaran piutang usaha merupakan rasio yang digunakan untuk mengukur barapa lama penagihan piutang selama satu periode atau berapa kali dana yang ditanam dalam piutang ini berputar dalam satu periode. Menurut Sartono (2010) menyatakn bahwa semakin cepat periode berputarannya piutang menunjukkan semakin cepat penjualan kredit dapat kembali menjadi kas. Tingkat perputaran piutang usaha dapat diketahui dengan membagi penjualan kredit bersih dengan rata-rata piutang dengan piutang (Haharap, 2010). 


\section{Pengertian Persediaan}

Perputaran persediaan menurut Munawir (2004) adalah perputaran persediaan menjukkan berapa kali persediaan yang dimiliki perusahaan diganti atau dijual selama periode tertentu. Sedangkan menurut Sugiyarso dan Winarni (2003) rasio perputaran persediaan adalh mengukur berapa kali persediaan perusahaan yang telah terjual selama periode tertentu, sedangkan jumlah hari persediaan menunjukkan berapa lama persediaan itu tersimpan dalam gudang. Perputaran persediaan dalam perusahaan menunjukkan kinerja perusahaan dalam aktivitas operasionalnya. Semakin tinggi tingkat perputaran persediaan, kemungkinan semakin besar perusahaan akan memperoleh keuntungan. Begitu pula sebaliknya, jika tingkat perputaran persediaannya rendah maka kemungkinan semakin kecil perusahaan akan memperoleh keuntungan (Raharjaputra, 2009).

\section{Pengaruh Perputaran Piutang Usaha terhadap Profitabilitas}

Riyanto dalam Manullang dan Sinaga (2005) perusahaan harus menyediakan investasi yang lebih besar dalam piutang, dan meski memiliki risiko semakin besar, profitabilitasnya juga akan meningkat. Salah satu cara untuk menilai berhasil atau tidaknya kebijakan penjualan kredit yang dilaksanakan oleh perusahaan dapat dilakukan dengan melihat perputaran piutang usahanya. Syamsuddin (2009) dalam Kurnia (2013) menjelasan yaitu semakin tinggi account receivable turn over suatu perusahaan semakin baik pengelolaan piutangnya. Account receivable turn over dapat ditingkatkan dengan jalan memperketat kebijaksanaan penjualan kredit, misalnya dengan memperpendek waktu pembayaran.

Sufiana dan Purnawati (2010) menujukkan hasil penelitian bahwa perputaran piutang usaha berpengaruh positif dan signifikan terhadap profitabilitas pada perusahaan food and beverage di BEI tahun 2005-2009. Penelitian oleh Venti Linda (2013) menunjukkan bahwa perputaran piutang usaha berpengaruh positif dan signifikan terhadap profitabilitas pada perusahaan tekstil yang terdaftar di BEI.

Agustia Dewi (2014) menunjukkan hasil penelitian nya adalah bahwa perputaran piutang usaha berpengaruh positif dan signifikan terhadap profitabilitas pada perusahaan manufaktur yang terdaftar di Bursa Efek Indonesia tahun 2014.

Dari uraian diatas, dapat dikembangkan bahwa hipotesis yang pertama adalah

Diduga Perputaran Piutang usaha berpengaruh positif dan signifikan terhadap tingkat Profitabilitas pada Perusahaan Food and Beverage yang terdaftar di Bursa Efek Indonesia.

\section{Pengaruh Perputaran Persediaan terhadap Profitabilitas}

Pengelolaan persediaan merupakan suatu pekerjaan yang sulit, diaman kesalahan dalam menentukan tingkat persediaan dapat berakibat fatal. Semakin tinggi tingkat perputaran persediaan, kemungkinan semakin besar perusahaan akan memperoleh keuntungan. Perputaran persediaan menunjukkan berapa kali persediaan tersebut dijual dan diganti dalam waktu satu periode. Semakin tingkat perputaran persediaan barang, maka semakin tinggi biaya yang dapat ditekan sehingga samkin besar perolehan laba suatu perusahaan. Sebaliknya, jika semakin lambat perputaran persediaan maka semakin kecil pula perolehan labanya.

Putriwati (2016) menunjukkan bahwa perputaran persediaan berpengaruh positif dan signifikan terhadap profitabilitas pada perusahaan tekstil yang terdaftar di Bursa Efek Indonesia. Penelitian Nina Sufiana (2011) dan Iqbal (2015) 
menunjukkan bahwa perputaran persediaan berpengaruh positif dan signifikan terhadap profitabilitas pada perusahaan food and beverage tahun 2009-2013.

Venti Linda (2014) menunjukkan bahwa perputaran persediaan berpengaruh positif dan signifikan terhadap profitabilitas pada perusahaan tekstil yang terdaftar di BEI. Agustia Kadek (2016) menunjukkan juga bahwa perputaran persediaan berpengaruh positif fan signifikan pada perusahaan manufaktur yang terdaftar di BEI.

Dari uraian diatas, dapat dikembangkan bahwa hipotesis yang kedua adalah

Diduga Perputaran Persediaan berpengaruh positif dan signifikan terhadap Tingkat Profitabilitas pada Perusahaan Food and Beverage yang terdaftar di Bursa Efek Indonesia.

\section{METODE PENELITIAN}

Jenis penelitian yang di dalam penelitian ini adalah penelitian kuantitatif. Menurut Sugiyono (2006) penelitian kuantitatif merupakan penelitian empiris dimana data adalah dalam bentuk sesuatu yang dapat dihitung atau angka. Penelitian kuantitatif data yang berbentuk angka atau bilangan yang diambil dari laporan keuangan mengenai perputaran piutang usaha, perputaran persediaan dan profitabilitas pada perusahaan Food and Beverage yang terdaftar di Bursa Efek Indonesia. Objek penelitian ini adalah perusahaan food and beverage yang terdaftar di Bursa Efek Indonesia tahun 2011-2015.

Menurut Sugiyono (2006:72) Populasi adalah wilayah generalisasi yang terdiri atas objek atau subjek yang mempunyai kualitas dan karakteristik tertentu yang ditetapkan oleh peneliti untuk dipelajari, kemudian ditarik kesimpulannya. Populasi yang digunakan dalam penelitian ini adalah perusahaan food and beverage yang terdaftar di BEI selama tahun 2011-2015 yang berjumlah 14 perusahaan.

Sampel adalah bagian dari jumlah karakteristik yang dimiliki oleh populasi tersebut (Sugiyono, 2006 : 73). Penelitian ini mengambil sampel perusahaan food and beverage yang terdaftar di BEI pada tahun 2011-2015 yang diambil dengan menggunakan metode purposive sampling yaitu populasi yang akan dijadikan sampel penelitian adalah yang memenuhi kriteria sampel tertentu sesuai dengan yang dikehendaki peneliti dan kemudian dipilih berdasarkan pertimbangan tertentu yang disesuaikan dengan tujuan penelitian. Adapun kriteria pemelihan sampel adalah sebagai berikut : (1) Perusahaan food and beverage yang terdaftar di Bursa Efek Indonesia tahun 2011-2015. (2) Perusahaan food and beverage yang mempunyai laporan keuangan yang lengkap tahun 2011-2015. (3) Perusahaan food and beverage yang mengalami laba selama periode pengamatan, yang diambil laba bersih perusahaan. (4) Perusahaan food and beverage yang mempunyai piutang usaha selama periode pengamatan pada tahun 2011-2015. (5) Perusahaan food and beverage yang mempunyai persediaan selama periode pengamatan pada tahun 2011-215. Berdasarkan kriteria di atas sehingga terdapat 10 perusahaan food and beverage yang menjadi sampel penelitian yaitu :

1. PT Tiga Pilar Sejahtera Food Tbk.

2. PT Wilmar Cahaya Indonesia Tbk.

3. PT Indofood CBP Sukses Makmur Tbk.

4. PT Indofood Sukses Makmur Tbk. 
5. PT Mayora Indah Tbk.

6. PT Prashida Aneka Niaga Tbk.

7. PT Nippon Indosari Corporindo Tbk.

8. PT Sekar Laut Tbk.

9. PT Siantar Top Tbk

10. PT Ultrajaya Milk Industry and Tranding Company Tbk.

Jenis dan sumber data pada penelitian ini adalah berupa data sekunder bersifat kuantitatif. Dalam penelitian ini, peneliti menggunakan data panel, yaitu merupakan kombinasi dari data time series dan cross-section. Data sekunder yang digunakan dalam penelitian ini adalah laporan keuangan yang berhubungan dengan variabel penelitian. Teknik pengumpulan data pada penelitian ini adalah dengan studi kepustakaan dan observasi secara langsung dengan melihat laporan keuangan perusahaan secara online.

\section{Defenisi Operasional Variabel}

\begin{tabular}{|c|c|c|c|}
\hline No & Variabel & Defenisi & Pengukuran \\
\hline 1 & Profitabilitas & $\begin{array}{l}\text { Merupakan rasio yang } \\
\text { digunakan untuk } \\
\text { membandingkan } \\
\text { antara laba bersih } \\
\text { perusahaan dengan } \\
\text { total asset perusahaan. }\end{array}$ & ROI $=\frac{\text { Laba bersih }}{\text { Total asset }} \quad=\ldots \ldots \%$ \\
\hline 2 & $\begin{array}{l}\text { Perputaran } \\
\text { Piutang } \\
\text { Usaha }\end{array}$ & $\begin{array}{l}\text { Perputaran piutang } \\
\text { usaha merupakan rasio } \\
\text { yang digunakan untuk } \\
\text { mengukur berapa lama } \\
\text { penagihan piutang } \\
\text { selama satu periode } \\
\text { atau berapa kali dana } \\
\text { yang ditanam dalam } \\
\text { piutang ini berputar } \\
\text { dalam satu periode. }\end{array}$ & $\begin{array}{l}\text { Rasio Perputaran Piutang Usaha } \\
=\frac{\text { Penjualan Kredit Bersih }}{\text { Rata-rata Piutang }}=\ldots \text { kali }\end{array}$ \\
\hline 3 & $\begin{array}{l}\text { Perputaran } \\
\text { Persediaan }\end{array}$ & $\begin{array}{l}\text { Merupakan perputaran } \\
\text { persediaan (inventory } \\
\text { turnover) mengukur } \\
\text { hubungan antara } \\
\text { volume barang dagang } \\
\text { yang dijual dengan } \\
\text { jumlah persediaan } \\
\text { yang dimiliki selama } \\
\text { periode berjalan }\end{array}$ & $\begin{array}{l}\text { Perputaran Persediaan } \\
=\frac{\text { Harga pokok penjualan }}{\text { Rata-rata persediaan }}=\ldots \text { kali }\end{array}$ \\
\hline
\end{tabular}

Teknik analasis data pada penelitian ini adalah menggunakan uji teknik analisis deksriptif dimana melihat seberapa erat hubungan antara variable $\mathrm{x}$ dan $\mathrm{y}$. kemudian menggunakan uji asumsi klasik yang terdiri dari uji normalitas, uji heteroskedasititas, uji multikolonieritas, dan uji autokorelasi. Selanjutnya analisis 
regresi berganda, uji kelayakan model dengan menguji uji F, uji t, dan uji $R^{2}$. Rumus persamaan uji regresi berganda adalah sebagai berikut:

Dimana :

$$
\mathrm{Y}_{\text {it }}=\beta o+\beta 1 \mathrm{X}_{1 \mathrm{it}}+\beta 2 \mathrm{X}_{2 \mathrm{it}}
$$

$\mathrm{Y}_{\text {it }} \quad=$ Profitabilitas

Bo $\quad=$ Konstanta

$\beta 1-\beta 2=$ Koefisien regresi

$\mathrm{X}_{1 \text { it }} \quad=$ Perputaran piutang usaha

$\mathrm{X}_{2 \mathrm{it}} \quad=$ Perputaran persediaan

$\varepsilon=$ error

\section{HASIL DAN PEMBAHASAN}

Variabel yang diukur dalam penelitian ini yaitu perputaran piutang usaha, perputaran persediaan, dan return on invesment. Berikut penjelasan kondisi variabel perputaran piutang usaha, perputaran persediaan, dan Return on invesment (ROI) pada perusahaan food and beverage yang terdaftar di Bursa Efek Indonesia tahun 2010-2015. Hasil pengujian statistik deskriptif pada penelitian ini disajikan pada tabel 1 berikut :

Tabel 1

Deskriptif Statistik

\begin{tabular}{lccc}
\hline ROI & $\begin{array}{c}\text { Perputaran Piutang } \\
\text { Usaha }\end{array}$ & $\begin{array}{c}\text { Perputaran } \\
\text { Persediaan }\end{array}$ \\
\hline Mean & 7.662400 & 10.05420 & 8.506800 \\
Maximum & 15.27000 & 22.22000 & 33.50000 \\
Minimum & 2.790000 & 2.160000 & 2.460000 \\
Std. Dev. & 3.425430 & 4.080290 & 7.197923 \\
Observations & 50 & 50 & 50 \\
\hline
\end{tabular}

Sumber: Hasil Olahan Statistik

\section{Profitabilitas (return on investment/ ROI)}

Untuk deskripsi nilai ROI secara menyeluruh terlihat pada Tabel 1 bahwa nilai rata-rata ROI tahun 2011-2015 sebesar 7,66 \%. Artinya secara rata-rata perusahaan food and beverage yang terdaftar di BEI mampu memperoleh keuntungan atau laba bersih sebesar 7,66 \% dari investasi yang ditanamkan.

Nilai maksimum ROI sebesar $15,27 \%$, artinya perusahaan tersebut mampu memperoleh keuntungan atau laba bersih sebesar 15,27 \% dari investasi yang ditanamkan. Nilai minimun sebesar $2,79 \%$, artinya perusahaan tersebut mengalami kerugian sebesar $2,79 \%$ dari investasi yang ditanamkan. Perusahaan memiliki standar deviasi ROI sebesar 3,42 artinya tingkat penyimpangan ROI relatif kecil pada masing-masing perusahaan food and beverage di BEI memiliki tingkat keuntungan yang bervariasi dari investasi yang dimiliki, karena nilainya lebih kecil daripada mean-nya yaitu $7,66 \%$.

\section{Perputaran Piutang Usaha}

Dari Tabel 1 dapat diketahui bahwa rata-rata nilai perputaran piutang usaha tahun 2011-2015 pada perusahaan food and beverage sebesar 10,05 kali, artinya 
untuk mengubah piutang menjadi kas dilakukan sebanyak 10,05 kali. Nilai maksimun sebesar 20,22 kali, artinya kemampuan perusahaan untuk mengubah piutang menjadi kas sebesar 20,22 kali. Nilai minimum sebesar 2,16 kali, artinya kemampuan perusahaan untuk mengubah piutang menjadi kas hanya sebanyak 2,16 kali. Standar deviasi perusahaan sebesar 4,08 menunjukkan simpangan data yang relatif kecil, karena nilainya yang lebih kecil daripada nilai mean-nya yaitu sebesar 10,05 kali.

\section{Perputaran Persediaan}

Dari Tabel 1 dapat dilihat rata-rata nilai perputaran persediaan tahun 20112015 sebesar 8,50 kali. Artinya untuk mengubah persediaan menjadi penjualan dilakukan sebanyak 8,50 kali. Nilai maksimun sebesar 33,50 kali, artinya kemampuan perusahaan untuk mengubah persediaan menjadi penjualan sebesar 33,50 kali. Nilai minimum sebesar 2,46 kali, artinya kemampuan perusahaan untuk mengubah persediaan menjadi penjualan hanya sebanyak 2,46 kali. Standar deviasi perusahaan yaitu sebesar 7,19 kali artinya menunjukkan simpangan data yang relatif kecil, karena nilainya lebih kecil daripada mean-nya yaitu 8,50 kali.

\section{Uji Asumsi Klasik \\ a. Uji Normalitas}

\section{Tabel 2}

Hasil Normalitas Data

\begin{tabular}{lr}
\hline Mean & $-2.31 \mathrm{E}-15$ \\
Median & -0.787952 \\
Maximum & 7.647779 \\
Minimum & -4.595225 \\
Std. Dev. & 3.165809 \\
Skewness & 0.630935 \\
Kurtosis & 2.529774 \\
Jarque-Bera & 3.777973 \\
Probability & 0.151225 \\
& \\
Sum & $-1.15 \mathrm{E}-13$ \\
Sum Sq. Dev. & 491.0950 \\
& \\
Observations & 50 \\
Sumber $:$ data diolah &
\end{tabular}

Dilihat pada Tabel 2 di atas bahwa data variabel dalam penelitian ini normal, dimana nilai pada probability sebesar 0.151225 dimana probability $>0.05$ sehingga data dapat dikatakan berdistribusi normal. 


\section{b. Uji Heteroskedastisitas}

\section{Tabel 3}

\section{Hasil Uji Heteroskedasitas}

\begin{tabular}{llll}
\hline F-statistic & 1.456924 & Prob. F $(5,44)$ & 0.2233 \\
\hline Obs ${ }^{*}$ R-squared & 7.102147 & Prob. Chi-Square(5) & 0.2123 \\
\hline
\end{tabular}

Sumber : Hasil olahan data Eviews

Dari Tabel 3 di atas dapat dilihat bahwa nilai Obs*R-Squared adalah sebesar 7.102147 dengan probability sebesar 0.2123 , dimana nilai probabilitas $>0.05$ sehingga didapatkan kesimpulan bahwa data tidak bersifat heteroskedasititas.

\section{c. Uji Multikolonieritas}

Tabel 4

Hasil Uji Multikoloneritas Perputaran Piutang Perputaran Persediaan Usaha (X1) (X2)

\begin{tabular}{lcc}
\hline $\begin{array}{l}\text { Perputaran Piutang Usaha } \\
\text { (X1) }\end{array}$ & 1 & 0.01284777295966038 \\
\hline Perputaran Persediaan (X2) & 0.01284777295966038 & 1
\end{tabular}

Sumber : Hasil olahan data Eviews

Berdasarkan pada tabel 4 hasil olahan data terlihat nilai korelasi antara sesama variabel independen dibawah 0,8 sehingga dapat dikatakan bahwa sesama variabel independen tidak memiliki hubungan multikoloneritas.

\section{d. Uji Autokorelasi}

Tabel 5

Hasil Uji Autokorelasi

\begin{tabular}{cl}
\hline Model & Durbin-Watson \\
\hline 1 & 1.064830 \\
\hline
\end{tabular}

Sumber : Hasil Olahan data Eviews

Tabel 5 di atas menunjukan hasil dari uji Durbin Watson adalah senilai 1.064830 dan berada pada daerah yang tidak terkena autokolerasi, sehingga dapat disimpulkan bahwa dalam model penelitian ini tidak mengandung masalah autokolerasi.

\section{e. Uji Regresi Berganda}

Tabel 6

Dependent Variable: Y

\section{Hasil Uji Regresi Linear Berganda}

Method: Least Squares

Date: 03/08/17 Time: 17:32

Sample: 150

Included observations: 50

\begin{tabular}{ccccc}
\hline \hline Variable & Coefficient & Std. Error & t-Statistic & Prob. \\
\hline \hline C & 5.686173 & 1.331763 & 4.269660 & 0.0001 \\
X1 & 0.041230 & 0.112793 & 0.365533 & 0.7164 \\
X2 & 0.183582 & 0.063939 & 2.871204 & 0.0061
\end{tabular}




\begin{tabular}{lrll}
\hline \hline R-squared & 0.151713 & Mean dependent var & 7.662400 \\
Adjusted R-squared & 0.115616 & S.D. dependent var & 3.425430 \\
S.E. of regression & 3.221333 & Akaike info criterion & 5.235592 \\
Sum squared resid & 487.7184 & Schwarz criterion & 5.350314 \\
Log likelihood & -127.8898 & Hannan-Quinn criter. & 5.279279 \\
F-statistic & 4.202892 & Durbin-Watson stat & 1.064830 \\
Prob(F-statistic) & 0.020929 & & \\
\hline \hline
\end{tabular}

Sumber : Data Eviews

Dari hasil pengolahan data pada tabel 6, diperoleh angka-angka atau persamaan, bila diuji dalam regresi berganda menjadi:

ROI $(Y)=5.686173+0.041230 \mathrm{X} 1+0.183582 \mathrm{X} 2$

\section{Pengujian Hipotesis}

\section{Uji Statistik $F$}

Dari tabel 6 dihasilkan nilai F-Statistic sebesar 4.202892 dengan nilai signifikan probability F-Statistic adalah 0.020929 , tingkat probabilitasnya lebih kecil dari 0,05 atau < 0,05. Hal tersebut mengidentifikasikan bahwa semua atau salah satu variabel yaitu Perputaran Piutang Usaha dan Perputaran Persediaan berpengaruh secara signifikan terhadap profitabilitas yang diukur dengan return on investment.

\section{Uji Statistik $t$}

Pada hipotesis pertama pada penelitian ini adalah diduga perputaran piutang usaha berpengaruh positif dan signifikan terhadap tingkat profitabilitas. Dari hasil pengolahan data dihasilkan perputaran piutang usaha menunjukkan $\mathrm{t}$ hitung 0.365533 dengan nilai yang tidak signifikan 0.7164 lebih dari tingkat alpha 0.05 dan koefisien $\beta$ sebesar 0.041230 menunjukkan nilai positif. Artinya Ha ditolak dan $\mathrm{H} 0$ diterima yaitu perputaran piutang usaha berpengaruh positif dan tidak signifikan terhadap profitabilitas ( return on invesment ).

Pada hipotesis kedua pada penelitian ini adalah diduga perputaran persediaan berpengaruh positif dan signifikan terhadap profitabilitas. Dari hasil pengolahan data yang dihasilkan perputaran persediaan menunjukkan $t$ hitung 2.871204 dengan nilai yang signifikan 0.0061 kurang dari tingkat alpha 0.05 dan koefisien $\beta$ sebesar 0.183582 menunjukkan positif. Artinya Ha diterima. Sehingga hipotesis yang diajukan diterima yaitu perputaran persediaan berpengaruh positif dan signifikan terhadap profitabilitas ( return on invesment ).

\section{Uji Koefisien Determinasi $\left(R^{2}\right)$}

Hasil estimasi pada Tabel 6 diperoleh nilai adjusted $\mathrm{R}^{2}$ sebesar 0.115616 . Hal tersebut berarti hanya 0.115616 profitabilitas perusahaan food and beverage yang terdaftar di BEI tahun 2011-2015 dapat dijelaskan oleh dua variabel independentnya secara bersama-sama, yaitu perputaran piutang usaha $\left(\mathrm{X}_{1}\right)$ dan perputaran persediaan $\left(\mathrm{X}_{2}\right)$. Sedangkan selebihnya lagi ditentukan oleh variabel diluar penelitian ini, misalnya penjualan, laba perusahaan, dan utang usaha. 


\section{Pengaruh Perputaran Piutang Usaha terhadap Profitabilitas}

Berdasarkan dari hasil uji hipotesis yang dilakukan bahwa perputaran piutang usaha (X1) tidak berpengaruh signifikan terhadap tingkat profitabilitas perusahaan food and beverage yang terdaftar di Bursa Efek Indonesia. Dimana nilai koefisien regresi pada perputaran piutang usaha (X1) sebesar 0.041230 bertanda negatif dengan nilai probability $0.7164>0,05$ yang berarti perputaran piutang usaha mempunyai pengaruh positif yang tidak signifikan terhadap Profitabilitas (Return On Invesment). Dengan demikian dapat dinyatakan hipotesis pertama ditolak.

Hasil penelitian ini sama dengan penelitian yang dilakukan oleh Putriwati (2016) menemukan bahwa perputaran piutang usaha tidak signifikan terhadap profitabilitas pada perusahaan manufaktur yang terdaftar di Bursa Efek Indonesia. Penelitian Ari Brasmanto (2011) dalam penelitiannya bahwa perputaran piutang usaha tidak signifikan terhadap profitabilitas pada PT.Pos Indonesia. Dan penelitian oleh Irman Deni (2014) bahwa perputaran piutang usaha tidak signifikan terhadap profitabilitas pada perusahaan manufaktur yang tedaftar di Bursa Efek Indonesia. Penelitian Wayan (2014) menemukan bahwa perputaran piutang usaha berpengaruh tidak signifikan pada tingkat profitabilitas pada perusahaan pembiayaan yang terdaftar di Bursa Efek Indonesia.

Dengan demikian hasil penelitian ini dan beberapa penelitian terdahulu menyatakan bahwa perputaran piutang usaha tidak memiliki pengaruh pada tingkat profitabilitas yang didapatkan oleh perusahaan food and beverage yang terdaftar di Bursa Efek Indonesia pada tahun 2011-2015. Hal ini terjadi karena dalam pemberian syarat kredit yang ditetapkan oleh perusahaan terlalu ketat yang artinya perusahaan lebih mengutamakan keselamatan kredit daripada pertimbangan profitabilitas. Syarat yang ketat misalnya dalam bentuk batas pembayaraanya yang cukup pendek, pembebanan bunga yang berat pada pembayaran piutang yang terlambat.

\section{Pengaruh Perputaran Persediaan terhadap Profitabilitas}

Berdasarkan dari hasil uji hipotesis yang dilakukan bahwa perputaran persediaan (X2) berpengaruh signifikan terhadap tingkat profitabilitas perusahaan food and beverage yang terdaftar di Bursa Efek Indonesia pada tahun 2011-2015. Dimana nilai koefisien regresi pada perputaran persediaan (X2) sebesar 0.183582 bertanda positif dengan nilai probability $0.0061<0,05$ yang berarti perputaran persediaan mempunyai pengaruh positif yang signifikan terhadap Profitabilitas (Return On Invesment). Penelitian ini menunjukkan hubungan yang signifikan antara perputaran persediaan terhadap profitabilitas. Dengan demikian dapat dinyatakan hipotesis kedua diterima.

Nina Sufiana (2011) dan Iqbal, dkk (2015) menunjukkan bahwa secara parsial perputaran persediaan berpengaruh positif yang signifikan terhadap profitabilitas pada perusahaan food and beverage. Putriwati (2016) menujukkan bahwa perputaran persediaan berpengaruh positif dan signifikan terhadap profitabilitas pada perusahaan manufaktur sektor industri dasar dan kimia sub sektor keramik porselen dan kaca pada tahun 2011-2014. Penelitian ini juga didukung oleh Venti Linda (2014) dalam penelitiannya menunjukkan juga bahwa perputaran persediaan berpengaruh positif dan signifikan terhadap profitabilitas pada perusahaan tekstil. Agustia Kadek, dkk (2016) menunjukkan juga bahwa 
perputaran persediaan berpengaruh positif dan signifikan terhadap profitabilitas pada perusahaan manufaktur yang terdaftar di Bursa Efek Indonesia.

Dengan demikian hasil penelitian ini dan beberapa penelitian terdahulu menyatakan bahwa perputaran persediaan memiliki pengaruh pada tingkat profitabilitas pada perusahaan food and beverage yang terdaftar di Bursa Efek Indonesia pada tahun 2011-2015. Dimana pada saat terjadi peningkatan pada perputaran persediaan ternyata diikuti juga oleh meningkatkannya profitabilitas perusahaan.

\section{KESIMPULAN DAN SARAN \\ Kesimpulan}

Perputaran piutang usaha memiliki pengaruh positif yang tidak signifikan terhadap tingkat profitabilitas perusahaan food and beverage yang terdaftar di Bursa Efek Indonesia pada tahun 2011-2015 yang ditunjukkan dengan nilai profitabilitas lebih besar dari 0,05 yaitu sebesar 0.7164. Dimana semakin meningkatnya atau cepatnya perputaran piutang usaha tidak akan mempengaruhi peningkatan profitabilitas yang dihasilkan perusahaan. Perputaran persediaan memiliki pengaruh positif dan signifikan terhadap tingkat profitabilitas perusahaan food and beverage yang terdaftar di Bursa Efek Indonesia pada tahun 2011-2015 yang ditunjukkan dengan nilai profitabilitas lebih kecil dari 0,05 yaitu sebesar 0,0061. Dimana semakin tinggi perputaran persediaan akan mempengaruhi peningkatan profitabilitas yang dihasilkan oleh perusahaan food and beverage yang terdaftar di Bursa Efek Indonesia pada tahun 2011-2015.

\section{Saran}

Bagi perusahaan, agar lebih memperhatikan kebijakan kredit yang ditetapkan dan tidak terlalu fokus pada target atau omset yang dicapai. Maka dari itu perusahaan harus memikirkan juga bagaimana pengelolaan, pengawasan dalam pemberian dan penagihan piutang usaha.

Bagi peneliti selanjutnya, diharapkan meneliti faktor-faktor lain yang mempengaruhi profitabilitas perusahaan dan melakukan penelitian lanjutan dengan menambahkan variabel lain atau menambah periode pengamatan. Karena hasil dalam penelitian ini berbeda bahwa faktor perputaran piutang usaha berpengaruh positif dan tidak signifikan terhadap profitabilitas dan perputaran persediaan berpengaruh positif dan signifikan terhadap profitabilitas perusahaan.

\section{DAFTAR PUSTAKA}

Brigham, Eugene F dan Joel F Weston, (2001), Manajemen Keuangan, Erlangga, Jakarta.

Deni, Irman, 2012, Pengaruh Tingkat Perputaran Kas, Perputaran Piutang, dan Perputaran Persediaan Terhadap Profitabilitas Perusahaan Manufaktur Yang Go Publik Di Indonesia (Studi Empiris Pada Perusahaan Manufaktur Yang Terdaftar di PT. Bursa Efek Indonesia Periode 200920011), Skripsi, Jurusan Akuntansi, Fakultas Ekonomi, Universitas Maritim Raja Ali Haji.

Dewi, Agusti, (2015), Pengaruh Perputaran Kas, Perputaran Persediaan, dan 
Perputaran Piutang Terhadap Profitabilitas Pada Perusahaan Manufaktur Yang Terdaftar Di Bursa Efek Indonesia, Jurusan Manajemen, Universitas Pendidikan Ganesha, Singaraja.

Erawati, L., \& Dewi, A. S. (2019). Peran Profitabilitas Sebagai Variabel Interverning Dan Pengaruh Struktur Modal Terhadap Nilai Perusahaan. INA-Rxiv.

Fitri, Meria, (2013), Pengaruh Perputaran Piutang Usaha dan Perputaran Persediaan Terhadap Profitabilitas Perusahaan Otomotif Yang Terdaftar di PT. Bursa Efek Indonesia, Skripsi, Jurusan Manajemen, Fakultas Ekonomi, Universitas Negeri Padang.

Hadya, R., Begawati, N., \& Yusra, I. (2017). Analisis Efektivitas Pengendalian Biaya, Perputaran Modal Kerja, dan Rentabilitas Ekonomi Menggunakan Regresi Data Panel. Jurnal Pundi, 01(03), 1-35.

Hanafi, Mamduh, Abdul Halim, (2000), Analisa Laporan Keuangan, AMP-YKPN, Yogyakarta.

Handayani, F., \& Martha, L. (2019). Hubungan Antara Profitabilitas Dengan Nilai Perusahaan Yang Dimoderasi Oleh Corporate Social Responsibility. INARxiv.

Harahap, Sofyan Syafri, (2006), Analisis kritis atas laporan keuangan, Jakarta: PT. Raja Grafindo Persada.

I Made Sudana, (2011), Manajemen Keuangan Perusahaan, Erlangga, Jakarta.

Kasmir, (2008), Analisis Laporan Keuangan, PT. Raja Grafindo Persada, Jakarta.

Kurnia, Fransischa, (2013), Pengaruh Perputaran Kas, Perputaran Piutang Dan Perputaran Persediaan Terhadap Profitabilitas Pada Perusahaan Food And Beverage Yang Go Public Di Bursa Efek Indonesia, Universitas Pembangunan Nasional "Veteran", Jawa Timur.

Kurniawan, A., \& Yusra, I. (2019). Apakah profitabilitas dan nilai buku berdampak terhadap return saham?: studi empiris pada perusahaan LQ45. INA-Rxiv.

Linda, Venti, (2014), Pengaruh Modal Kerja, Perputaran Piutang, dan Perputaran Persediaan Terhadap Profitabilitas Perusahaan Tekstil Yang Terdaftar Di Bursa Efek Indonesia, Sekolah Tinggi Ilmu Ekonomi Indonesia (STIESIA), Surabaya.

Martha, L., Sogiroh, N. U., Magdalena, M., \& Susanti, F. (2018). Profitabilitas dan Kebijakan Dividen terhadap Nilai Perusahaan. Jurnal Benefita, 3(2), 227238.

Munawir, (2004), Analisisa Laporan Keuangan, Liberty, Yogyakarta.

Purnama, S., \& Mayliza, R. (2019). Nilai Perusahaan Di Lihat Dari Aspek Profitabilitas, Ukuran Perusahaan Dengan Struktur Modal Sebagai Variabel Intervening. INA-Rxiv.

Putra, A. D., \& Yusra, I. (2019). Peran profitabilitas dalam memoderasi pengaruh free cash flow terhadap kebijakan dividen di Indonesia. INA-Rxiv.

Putriwati, (2016), Pengaruh Perputaran Kas dan Perputaran Piutang Terhadap Profitabilitas Pada Perusahaan Manufaktur Sektor Industri Dasar Dan Kimia Sub Sektor Keramik, Porselen Dan Kaca Yang Terdaftar Di Bursa Efek Indonesia, Universitas Hasanuddin, Makasar.

Qusibah, V. L., \& Yusra, I. (2019). Profitabilitas , dan Ukuran Perusahaan Sebagai Faktor Penentu Leverage Perusahaan Di Indonesia. Jurnal Pundi, 03(01), 13-26. https://doi.org/10.31575/jp.v3i1.125 
Rangkuti, Freddy, (2004), Manajemen Persediaan (Aplikasi di Bidang Bisnis), cetakan keenam, PT. Raja Grafindo Persada, Jakarta.

Soemarso, (2004), Akuntasi Suatu Pengantar, Cetakan 1, Edisi Kelima, Salemba Empat, Jakarta.

Suad, Husnan, (1998), Manajemen Keuangan: Teori dan Penerapan Keputusan Jangka Pendek, Jilid 2, BPFE-Yogyakarta, Yogyakarta.

Sufiana, Nina, (2011), Pengaruh Perputaran Kas, Perputaran Piutang, Dan Perputaran Persediaan Terhadap Profitabilitas Perusahaan (Pada Perusahaan Industri Barang Konsumsi Yang Terdaftar di PT. Bursa Efek Indonesia), Skripsi, Jurusan Akuntansi, Fakultas Ekonomi, Universitas Udayana Bali.

Sugiyono, (2009), Metode Penelitian Pendidikan, Alfabeta, Jakarta.

Warren, Reeve, Fess, (2005), Pengantar Akuntansi. Penerbit Salemba Empat, Jakarta.

Yusra, I. (2016). Pertumbuhan Aktiva Produktif, dana Pihak Ketiga, dan Profitabilitas: Studi Empiris di BUrsa Efek Indonesia. Jurnal KBP, 03(02), 157-164. 